\title{
頭頸部扁平上皮癌に対する超選択的動注療法の 成績と合併症の検討
}

\author{
*1宮城県立がんセンター頭頸科 \\ *2東北大学医学部耳鼻咽喉科

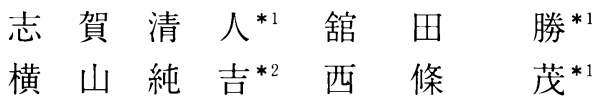

\begin{abstract}
論文要旨
平成 7 年 4 月より平成 11 年 8 月の間に当科では超選択動注療法が 76 症例に対し 213 回施行された。この うち扁平上皮癌 64 例で脱落例 5 例を除きKaplan-Meier 法により求めた 5 年生存率 (disease specific

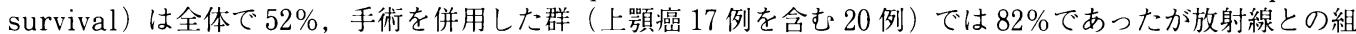
合せによる治療群（26 例）では 55\%であった。腎不全の合併はなかった。同じ時期に手術および放射線治療 （十静注化学療法）で治療を行った Stage III， IV 症例と超選択的動注療法十放射線療法で治療を行った Stage III，IV 症例を比較すると Kaplan-Meier 法により求めた 5 年生存率（disease specific survival） は手術群で $61 \%$, 動注群で $56 \%$ であった。 randomized study では無いため進行した症例が超選択的動注 療法十放射線療法で治療を行っている傾向があり，この結果は超選択的動注療法が全体の生存率を押し上げ ていると考えられる。再発例・二次治療例に対する動注化学療法＋放射線療法は姑息例に対して行われた放 射線単独あるいは静注化学療法との併用療法と比較しても予後に差がなかった。超選択的動注療法の脱落例 は 5 例あり脳梗塞 2 例, 突然死 1 例, 肺炎.DIC 1 例, ARDS 1 例と重篤なものが多く, 治療後も突然死, 出血死などがあった。また嚥下困難・呼吸困難を訴える症例もあり必ずしもQOLが良いとはいえなかった。
\end{abstract}

Key words：頭頸部扁平上皮癌（head and neck squamous cell carcinoma), 進行癌 (advanced cancer), 超選択的動注化学療法 (superselective intra-arterial chemotherapy), 生 存率 (survival rate), 合併症 (complication)

はじめに

頭頸部癌の治療にあたってはよりよく癌を根治させる ことと同時によりよく患者の咀嚼・嚥下・発声・構音な どの機能を保存することが要求され, 症例によっては後 者をある程度犠牲にせざるを得ない場合も多々ある。臓 器保存の立場から放射線治療と種々の化学療法が組み合 わされ患者の治療に用いられている。超選択的動注療法 は抗がん剂を高濃度で局所の癌組織に到達させようとす る考え方で始められたが，Robbins らの基礎的・臨床 的研究により ${ }^{1-5)}$, CDDP の中和剤を用いることにより その投与量を飛躍的に増加させることが可能となった。 これにより腫瘍内薬剤濃度を上昇させ，抗腫瘍効果をよ り増大させることが可能となった。我々の施設では平成 7 年の春よりこの方法を取り入れており, 開始後 5 年を 経過した。今後の治療に反映させるため,ここでその成

別刷請求先： $\mathbf{T} 981-1293$

名取市愛島塩手宇野田山 47-1

宮城県立がんセンター頭頸科

志賀清人
績と合併症について検討し評価を行った。

\section{対象および方法}

平成7年 4 月より平成 11 年 8 月の間に宮城県立がんセ ンター頭頸科では超選択的動注による化学療法が 76 例 に対して 213 回施行された（1症例あたり平均 2.8 回）。 このうち扁平上皮癌症例 64 例を対象としてその成績を 検討した。部位による内訳は上顎癌 23 例, 笠骨洞癌 1 例, 蝶形骨洞癌 1 例, 上咽頭癌 2 例, 中咽頭癌 13 例, 下咽頭癌 2 例, 舌癌 7 例, 菌肉癌 4 例, 煩粘膜癌 2 例, 口腔底癌 1 例, 喉頭癌 4 例, 頸部癌 (occult neck cancer） 3 例, 外耳道癌 1 例であった。その病期分類は Stage Iはなく, Stage IIが 7 例, Stage III 17 例, Stage IVが 40 例であった。このうち他院より紹介され た 2 次治療例は 8 例が全例 Stage IVであった。動脈造 影は一部浅側頭動脈から Sheath を留置して行った症例 を除き大腿動脈から Seldinger 法を用いて行い, 週 1 回の割合で $100-150 \mathrm{mg} / \mathrm{m}^{2}$ の CDDP を超選択的に 5 $\mathrm{mg} / \mathrm{min}$ の速度で注入した。CDDP 注入時に中心静脈 カテーテルを経由して $120 \mathrm{ml}-200 \mathrm{ml}$ のチオ硫酸ナトリ 
ウムを同時に持続注入した。また初期に血管痛や神経障 害が頻発したためその原因と考えられた CDDP の酸性 度を下げるため $1 / 20$ 量の重炭酸ナトリウム溶液（メイ ロン® ${ }^{\circledR}$ をCDDP 液に混合した。方法の詳細につい ては他の我々の報告を参照されたい ${ }^{6-8)}$ 。上顎癌などの 新鮮例では主に動注後手術を行い更に術後照射を加えた (動注十手術群)。中咽頭癌などで器官温存を図った症例 では動注後あるいはこれと平行して放射線治療を行い， 頸部転移が残存する例では頸部郭清術を追加した（動注 十放治群)。再発あるいは二次治療例は 13 例あった（再 発・二次治療群)。動注十放治群との比較のために検討 した手術を中心とした治療を行った扁平上皮癌症例 (Stage III, IV, 手術群) は 81 例で, Stage IIIが 22 例, Stage IV が 59 例, 部位別内訳は口唇癌 1 例, 舌癌 15 例, 口腔底癌, 3 例, 歯肉癌 4 例, 煩粘膜癌 2 例, 中咽頭癌 11 例, 下咽頭癌 20 例, 頸部食道癌 1 例, 喉頭癌 21 例, 顎下腺癌 1 例, 甲状腺癌 1 例, occult neck cancer 1 例であった。生存率は Kaplan-Meier 法により求め, 検定は log-rank 法を用いて行った。

\section{結 果}

\section{1. 脱落例についての検討}

超選択的動注療法の脱落例は 5 例あった（表 1 )。脳 梗塞が 2 例あり, 68 歳男性の中咽頭癌の再発例と 75 歳 女性の上顎癌の進行例でそれぞれ 2 回目, 4 回目の動注 後次の日の朝までに症状が出現した。いずれも片麻疸が 残存し，10 カ月後， 5 力月後にそれぞれ現病死した。 2 回目の動注後 4 日目の夜に浮腫によると思われる気道閉 塞で突然死した舌根部の中咽頭癌の症例が 1 例あった。 また動注化学療法による骨髄抑制によると思われる肺炎・
DIC 1 例，免疫不全が引き金になったと扔もわれる ARDS 1 例を経験し，それぞれ48日目，2ケ月目に合 併症死した。

2. 動注十放治群 (根治例), 動注十手術群, 再発 · 二次治療群に分類した生存率曲線の検討（図 1)

脱落例 5 例を除き動注療法を行った 59 例の生存率曲 線を動注十放治群（根治例）, 動注十手術群, 再発·二 次治療群に分けて求めた。Kaplan-Meier 法により求 めた 5 年生存率（overall survival）は全体で $49 \%$, 手術を併用した群（上顎癌 17 例を含む 20 例）では 78 \%であったが放射線との組合せによる治療群（26 例） では CR 率は $84 \%$ であったが 5 生率は $48 \%$ であった。 再発・二次治療群では成績が悪く 14 力月以内に全例死 亡していた。disease specific survival は全体で $52 \%$, 動注+手術群で $82 \%$, 動注十放治群（根治例）で $55 \%$ であった。overall survival, disease specific survival ともに動注十手術群と全体例間に有意差が認めら れ，また再発・二次治療群と他の 2 群間に有意差が認め られた。全症例について腎不全の合併はなかった。

3. Stage III, IV 症例での動注十放治群の治療内容· 成績と, 手術群との生存率の比較検討

動注を行った症例は手術を中心とした治療を行った症 例に比べて同じ病期分類でも進行例が多く，その中心と なると思われる原発巣に対して動注療法および放射線治 療を行い臟器温存を図った stage III ・ IV 症例 22 例につ いてまとめてみた（表 2)。 stage III が喉頭癌 3 例を含 めて 4 例, stage IV が 18 例であった。大腿動脈から Seldinger 法を用いて行ったのが 18 例, 浅側頭動脈経 由が 5 例で CDDP の量は $50 \mathrm{mg}$ から $1275 \mathrm{mg}$, 回数は 1-8 回だった。静注による化学療法を 5 例で併用し, 頸

表 1 超選択的動注化学療法 ·脱落例の検討

\begin{tabular}{|c|c|c|c|c|}
\hline & & $\begin{array}{c}\text { 動注回数 } \\
\text { CDDP総 }\end{array}$ & 合併症 & 転带 \\
\hline $68 \mathrm{M}$ & $\begin{array}{l}\text { 中咽頭瘦 } \\
\text { rN2a }\end{array}$ & $\begin{array}{c}2 \text { 回 · } \\
195 \mathrm{mg}\end{array}$ & $\begin{array}{l}\text { 脳梗塞· } \\
\text { 片麻㾝 }\end{array}$ & $\begin{array}{l}10 \text { 力月 } \\
\text { 原病死 }\end{array}$ \\
\hline $72 M$ & $\begin{array}{l}\text { 中咽頭癌 } \\
\text { T4N2cM0 }\end{array}$ & $\begin{array}{l}2 \text { 回· } \\
200 \mathrm{mg}\end{array}$ & $\begin{array}{l}\text { 気道閉塞 } \\
\text { 突然死 }\end{array}$ & $\begin{array}{l}\text { 動注 } 4 \text { 日目 } \cdot \text { 合併症死 } \\
\end{array}$ \\
\hline $56 \mathrm{~F}$ & $\begin{array}{l}\text { 上影䖵 } \\
\text { T4NOMO }\end{array}$ & $\begin{array}{c}4 \text { 回· } \\
850 \mathrm{mg}\end{array}$ & $\begin{array}{l}j つ \text { 病· } \\
\text { 肺炎 } \cdot \text { DIC }\end{array}$ & $\begin{array}{l}48 \text { 日目· } \\
\text { 合併症死 }\end{array}$ \\
\hline $75 \mathrm{M}$ & 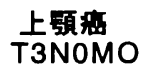 & $\begin{array}{l}\text { 4回· } \\
850 \mathrm{mg}\end{array}$ & $\begin{array}{l}\text { 脳梗塞・ } \\
\text { 片麻癗 }\end{array}$ & $\begin{array}{l}5 \text { 力月 } \\
\text { 原病死 }\end{array}$ \\
\hline 5. $64 \mathrm{M}$ & $\begin{array}{l}\text { 口整瘦 } \\
\text { T4N1M }\end{array}$ & $\begin{array}{c}\text { 3回· } \\
400 \mathrm{mg}\end{array}$ & ARDS & $\begin{array}{l}2 \text { 力月 } \\
\text { 合併庭死 }\end{array}$ \\
\hline
\end{tabular}


A. overall survival

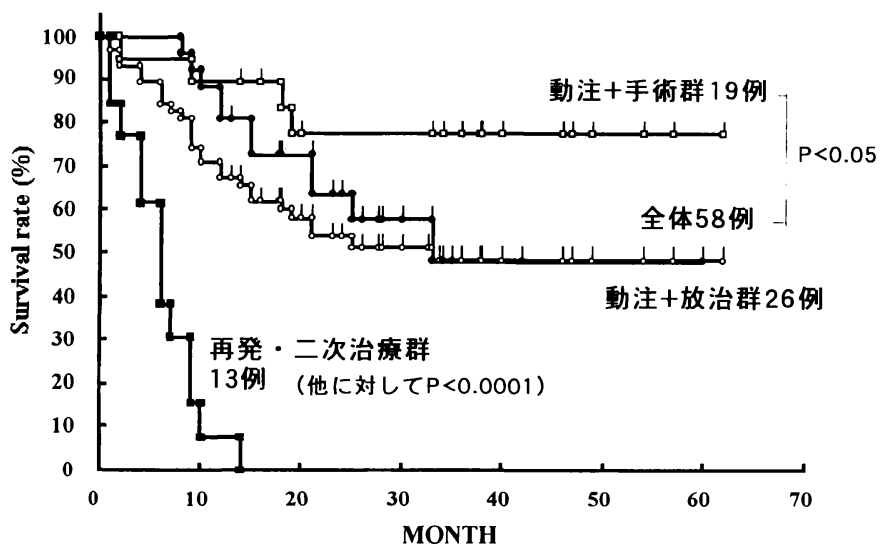

B. disease-specific survival

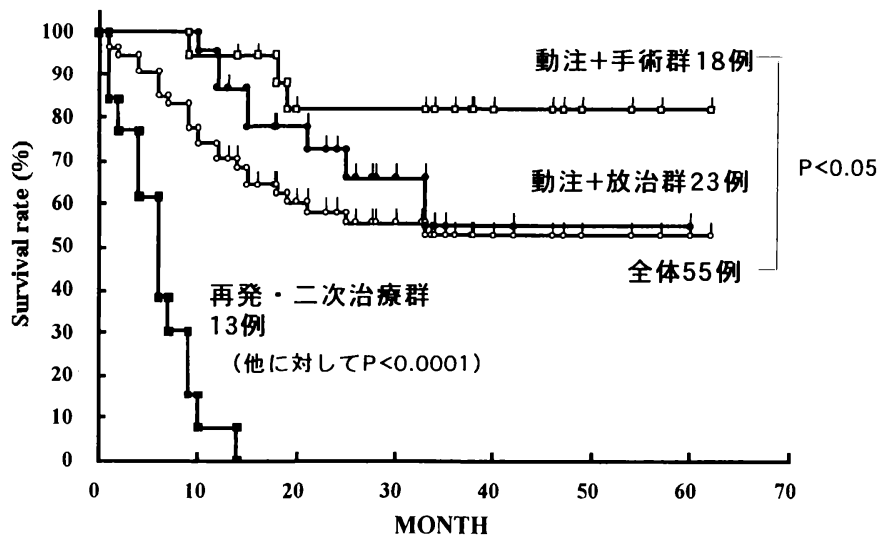

図 1 超選択的動注化学療法施行例の生存率曲線

表 2 超選択的動注化学療法 Stage III, IV 症例（放射線治療併用根治例）

\begin{tabular}{|c|c|c|c|c|c|c|c|c|c|}
\hline & 年㷍・性 & 部位 & TNM分颣 & 䄭注回数. CDDP松量 & 他治碾 & 放射緗量 & 治㲾効果 & 合併店その他 & 枟带 \\
\hline 1 & $84 \mathrm{M}$ & 中咽顽 & T2N1MO & 1 回. $50 \mathrm{mg}$ & & $65 \mathrm{~Gy}$ & $C R$ & & 21 カ月 - 原病死 \\
\hline 2 & $43 \mathrm{M}$ & 颢部 & TxN3MO & 2 回. $265 \mathrm{mg}$ & CF 1 回 & $58 G y$ & CR & 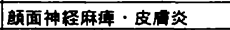 & 60 力月 $\cdot$ 生存 \\
\hline 3 & $88 \mathrm{M}$ & 预部 & TxN3MO & 1 回. CBDCA450mg & & $70 G y$ & $C R$ & & 33力月・原病死 \\
\hline 4 & $52 M$ & 下咽顽 & T2N3MO & 4 回. $600 \mathrm{mg}$ & CF2回 & 70Gy & $C R$ & 視量欠損 ·桐膡剥部 & 15 力月 $\cdot$ 原病死 \\
\hline 5 & $70 M$ & 榛粘厝 & T4NOMO & 3 回. $450 \mathrm{mg}$ & & 56Gy & CR & & 15 力月 - 原病死 \\
\hline 6 & $71 \mathrm{M}$ & 中因顽 & T2N3MO & 3 回. $450 \mathrm{mg}$ & ND & 60Gy & $C R$ & & 42力月・生存 \\
\hline 7 & $61 \mathrm{M}$ & 中咽顽 & T3N2bMO & 5 回. $700 \mathrm{mg}$ & ND & 69Gy & CR & 咽顽出血 & 35力月・生存 \\
\hline 8 & $51 \mathrm{M}$ & 中回顽 & \begin{tabular}{|l|} 
T4N1MO \\
\end{tabular} & 5 回(STA2回) $\cdot 750 \mathrm{mg}$ & & 69Gy & $C R$ & & 25 力月 - 他蕧死（食景） \\
\hline 9 & $73 \mathrm{~F}$ & 崌顽 & T3NOMO & 2 回 $(\mathrm{STA}) \cdot 130 \mathrm{mg}$ & CDDP50mgi.v.x2 & $64 G y$ & $C R$ & 行中呼吸毫止 & 34 力月・生存 \\
\hline 10 & $70 \mathrm{M}$ & 喉顽 & T3NOMO & 2 回(STA) $\cdot 100 \mathrm{mg}$ & CDDP50mgi.v. 66 & $70 \mathrm{~Gy}$ & $C R$ & 局所再無一喉顽部切 & 33カ月・生存 \\
\hline 11 & $58 \mathrm{M}$ & 曹肉 & T4N1M0 & 8 回. $1175 \mathrm{mg}$ & & $72 \mathrm{~Gy}$ & PR & & 10力月・原病死 \\
\hline 12 & $60 \mathrm{M}$ & 颂部 & TXN3MO & 4 回. $575 \mathrm{mg}$ & & $69 G y$ & $C R$ & 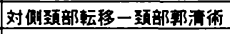 & 30力月・生存 \\
\hline 13 & $43 \mathrm{~F}$ & 上咽顽 & T4N3MO & 6 回. $975 \mathrm{mg}$ & & $66 G y$ & $C R$ & & 12 力月 - 原病死 (出血) \\
\hline 14 & $71 \mathrm{M}$ & 中咽厔 & T3N2aMO & 3 回. $475 \mathrm{mg}$ & & $70 \mathrm{~Gy}$ & CR & & 28力月・生存 \\
\hline 15 & $63 \mathrm{M}$ & 箁里洞 & T4NOMO & 7 回. $1275 \mathrm{mg}$ & & $71 \mathrm{~Gy}$ & PR & 前顽烡脱落 & 21 カ月 - 合併应死 \\
\hline 16 & $69 \mathrm{~F}$ & 中咽顽 & T2N2aMO & 4 回(STA) $.850 \mathrm{mg}$ & ND & $60 \mathrm{~Gy}$ & $C R$ & & 24カ月・生存 \\
\hline 17 & $59 M$ & 啹嗢 & T3NOMO & 2 回(STA) $\cdot 200 \mathrm{mg}$ & & $70 G y$ & $C R$ & カテーテル・トラフル & 23力月・生存 \\
\hline 18 & $52 \mathrm{M}$ & 上咽顽 & $\mathrm{T} 4 \mathrm{~N} 1 \mathrm{M} 0$ & 4 回 $\cdot 1000 \mathrm{mg}$ & 5Fu併用 3 回 & $65 \mathrm{~Gy}$ & PR & & 21 力月・生存 \\
\hline 19 & $63 \mathrm{M}$ & 中咽副 & T4NOMO & 4 回. $700 \mathrm{mg}$ & & $71 \mathrm{~Gy}$ & $C R$ & & 12力月・原病死（出血） \\
\hline 20 & $44 \mathrm{M}$ & 喉顽 & T3N2aMO & 7 回. $895 \mathrm{mg}$ & ND & $71 \mathrm{~Gy}$ & $C R$ & & 8力月・突然死 \\
\hline 21 & $43 \mathrm{M}$ & 中咽面 & T4NOMO & 3 回. $500 \mathrm{mg}$ & & $66 \mathrm{~Gy}$ & PR & 局所再発一根治術 & 17カ月・生存 \\
\hline 22 & $61 \mathrm{M}$ & 中咽梪 & T2N3MO & 2 回. $300 \mathrm{mg}$ & ND & $70 \mathrm{~Gy}$ & CA & & 13力月・生存 \\
\hline
\end{tabular}




\section{A. overall survival}

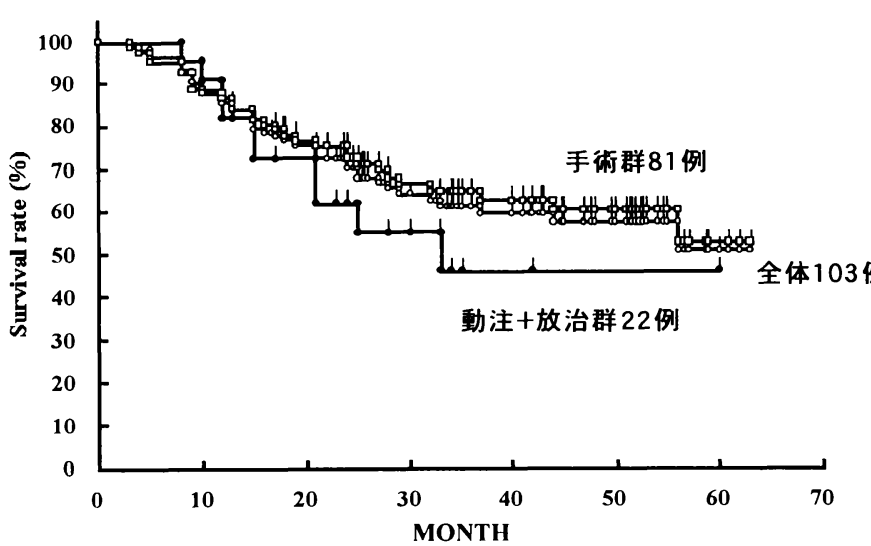

\section{B. disease-specific survival}

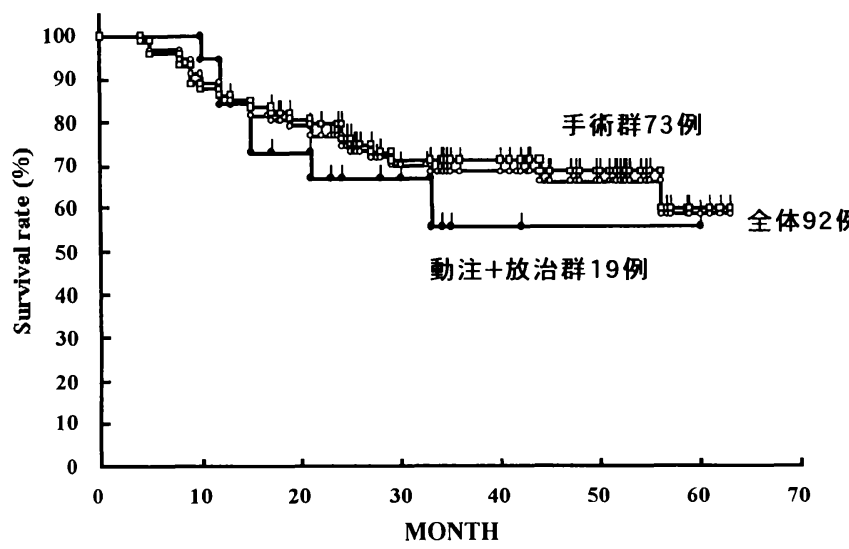

図 2 Stage III ・ IV 症例の生存率曲線

部郭清術を 5 例で行っている。放射線治療は $56 \mathrm{~Gy}$ から $72 \mathrm{~Gy}$ で，一部で不均等分割照射を併用している。原発 单に対する効果は CR 18 例, PR 4 例, 奏効率 $100 \%$, CR 率 $82 \%$ であった。術中に呼吸停止・カテーテルト ラブル, 術直後に顔面神経麻疩, 網膜剥離・視野久損な どの合併症，その後皮䖉炎や咽頭出血などもあり，さら に放射線による壊死によると思われる前頭葉の脱落を来 した症例もあった。転帰は他癌死 1 例, 原病死 7 例（出 血死 2 例を含む), 気道閉塞によると思われる突然死 1 例があった。原病死した症例はすべて局所再発によるも のであった。また治療後に嚥下困難・呼吸困難を訴える 症例もあり必ずしもQOL が良いとはいえなかった。

同じ時期に手術拉よび放射線治療 (十静注化学療法) で治療を行った Stage III, IV 症例 81 例と超選択的動注 療法十放射線療法で治療を行った Stage III，IV 症例 22 例を比較すると Kaplan-Meier 法により求めた 5 年生 存率（overall survival）は手術群で $53 \%$, 動注群で
45\%で手術群の方がやや予後が良好であったが有意差は なかった（図 2)。disease specific survival は手術群 73 例で $61 \%$, 動注群 19 例で $56 \%$, 全体で $59 \%$ であっ た。

4. T4, N3 症例に対する動注十放治群，手術群の生 存率の検討

3.で検討した症例のうちさらに最も進行していると 考えられる T4 あるいは N3 症例を抽出し動注十放治群 ( T4 が 8 例, N 3 が 7 例), 手術群 ( $\mathrm{T} 4$ が 18 例, N 3 が 3 例）でその 4 年生存率（overall survival）を比較した (図 3)。動注十放治群 14 例では $28 \%$ ，手術群では $53 \%$, 全体で44\%であった。disease specific survival は手 術群 18 例で $62 \%$, 動注群 13 例で $32 \%$, 全体で $50 \%$ で あった。 T4 症例だけを抽出して比較すると disease specific survival は手術群 16 例で $62 \%$, 全体で $48 \%$ であったが動注群は観察期間が短く評価不能であった (図 4A）。同様にN3 症例だけで見ると今度は逆に 


\section{A. overall survival}

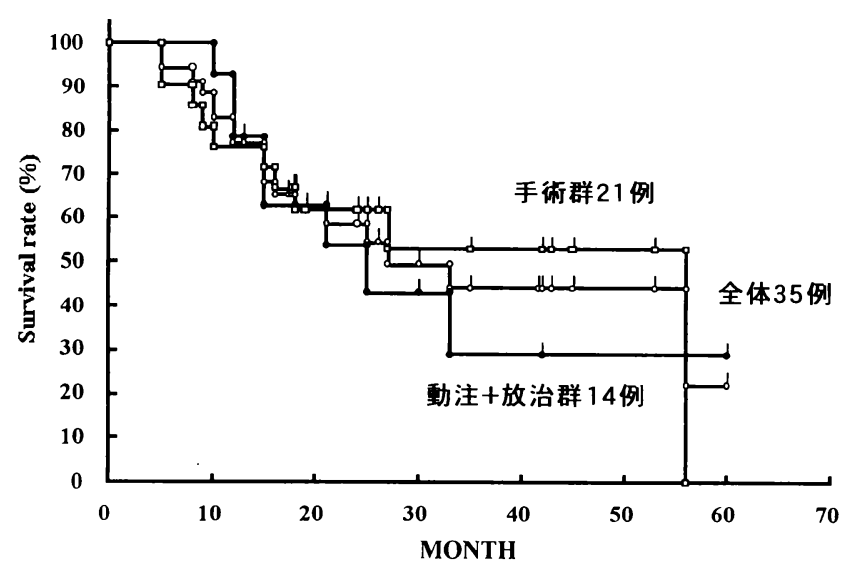

B. disease-specific survival

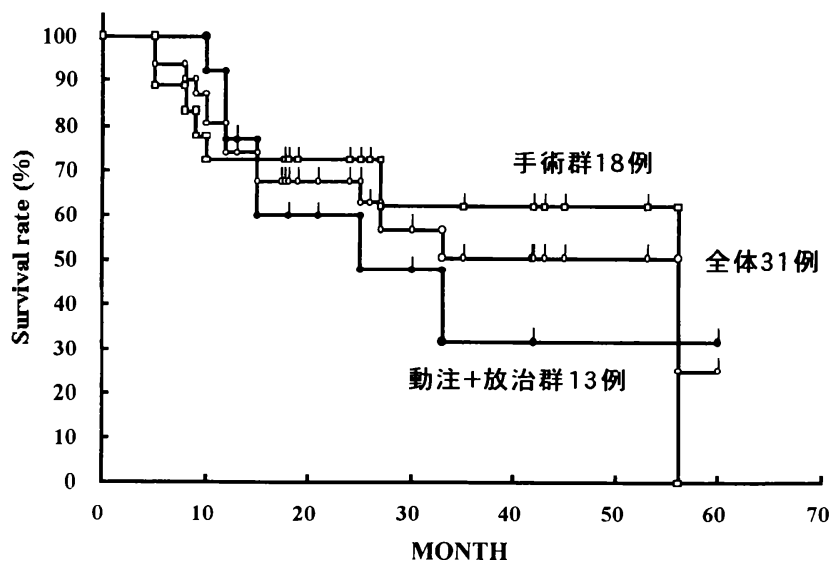

図 $3 \mathrm{~T} 4 / \mathrm{N} 3$ 症例の生存率曲線

disease specific survival は動注群が 46\%, 全体で $43 \%$ であったが手術群は観察期間が短く評価不能であっ た（図 4B)。

5. 再発・二次治療例に対する動注療法の有効性の検 討

再発・二次治療例に対して動注療法を行ったのは Stage III が 1 例, Stage IVが 12 例であるが, 全例 PR 以上の治療効果は得られなかった。その生命予後に対す る効果を検討するため, 同じ時期に放射線単独あるいは 放射線十静注化学療法で治療した姑息治療例（Stage III が 1 例, Stage IVが 7 例）との比較を行った。図 5 に示 したように両群間には殆ど差がなかった。両群とも動注 十放治群（Stage III，IVの根治例）との間には有意の差 が認められた。

\section{考察}

超選択的動注療法を行い原発巣に対する手術を併用し た症例ではその治療成績は非常によかった。その症例の 大部分は上顎癌であるが, これは上顎動脈が終末動脈で あり動注療法に好適な環境下にあるからかもしれない。 しかしながら動注療法で最も期待されるのは臓器保存で あり，その最も良い適応となるのは Stage III，IVの口 腔・咽頭癌であろう。そこで超選択的動注療法十放射線 療法で治療を行ったStage III，IV 症例を同じ時期に手 術および放射線治療（十静注化学療法）で治療を行った Stage III, IV 症例と比較すると手術群の方がやや子後 が良好であった。この傾向は T4 症例に限っても同じで あったがいずれも randomized study では無くより進 行した症例が超選択的動注療法十放射線療法で治療を行っ ている傾向があり，この結果はむしろ超選択的動注療法 


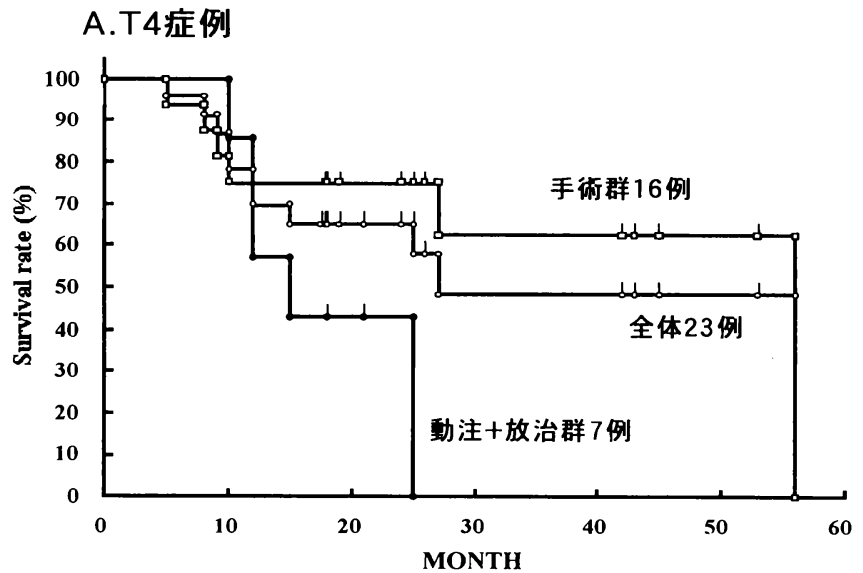

B. N3 症例

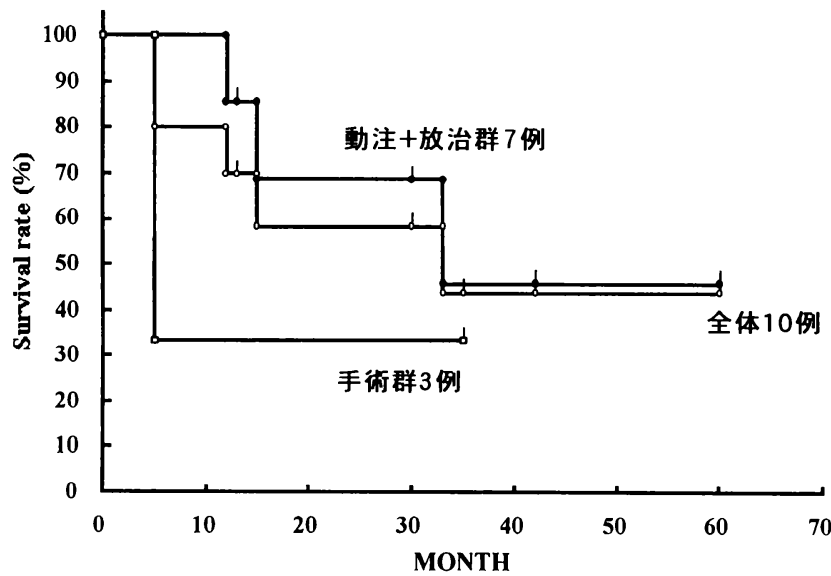

図 $4 \mathrm{~T} 4$ 抢よび N3 症例の生存率曲線

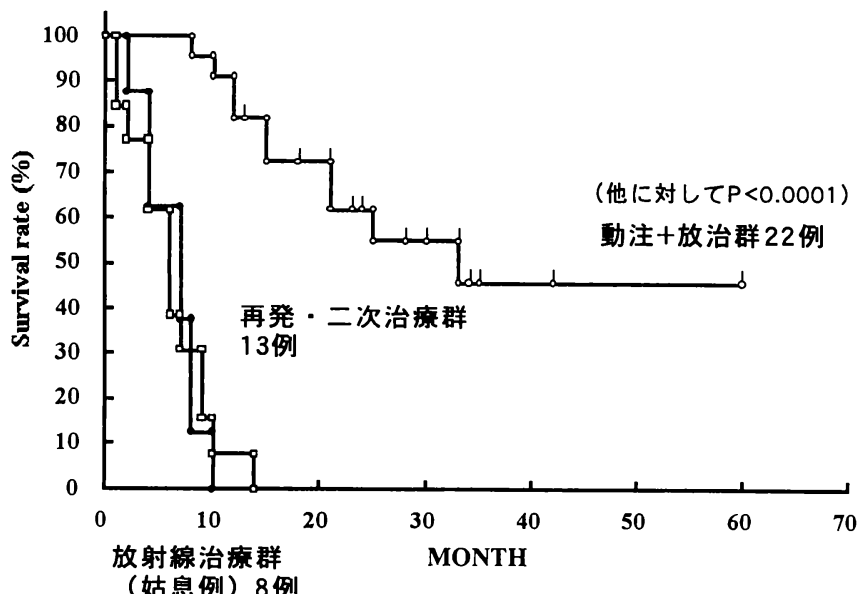

図 5 再発・二次治療例に対する超選択的動注化学療法施行例の生存率曲線一放射線治療群（姑 息例) との比較 (overall survival) 
が全体の生存率を押し上げ比較的良いと考えられる生存 率を得ていると考えられる。Robbins らの報告 ${ }^{4.5} に よ$ れば同じく Stage III，IV 症例 83 例に対して行われた動 注十放射線治療の結果, Kaplan-Meier 法により求め た 5 年生存率は, overall survival で $40 \%$, disease specific survival で $58 \%$ であり，ほぼ我々の結果と同 じであった。 $\mathrm{N} 3$ 症例に関しては症例が少ないながら手 術群を上回る 4 生率が観察されており今後の治療症例の 積み重ねによりその効果が明らかになることが期待され る。

超選択的動注療法の脱落例をみると, 脳梗塞 2 例, 突 然死 1 例, 肺炎·DIC 1 例, ARDS 1 例と重篤なもの が多く, 治療後も突然死，出血死などがあった。また燕 下困難・呼吸困難を訴える症例もあり手術を中心とした 治療を行った症例と比較して必ずしもQOLが良いとは いえなかった。脳血管障害については Robbins らが 323 回の動注で 6 回の合併があったと報告している ${ }^{4,5)}$ 。 当科でも 213 回（76 症例）の動注術で 2 例経験してお り，その頻度は欧米人との身体的差異を考慮しても妥当 だと考えられるが，重篤な合併症でもあり，100回の動 注術を行えば 1 回は起こる可能性があることを知り, 患 者への十分な説明とコンセンサスの形成が重要だと考え られる。

これまでの結果を踏まえ，より良い成績を得，合併症 を少なくするための今後の課題を列挙すると,

1. 超選択的動注療法は $\mathrm{CR}$ 率が高く腫瘍縮小効果 に優れている。手術可能な症例であれば腫瘍が切除可能 となった時点で出来る限り早期に手術を行った方がよい。

2. 高齢になると脳血管障害の危険性が增すので出来 る限り避ける。また喉頭・中咽頭の症例で呼吸不全によ ると思われる突然死があったので喉頭浮腫を惹起しそう な部位はできるだけ避けるか, 薬剤量を少なくした方が よい。

3. 中咽頭・上咽頭の症例で出血死があり治療による 粘膜欠損・潰瘍形成が原因と考えられたのでこれらの部 位の大きな腫瘍に対して超選択的動注を行う際には注意 を要する。

4. 骨髄抑制・免疫不全が原因と考えられる肺炎・ ARDS を合併した症例があり治療期間中は厳重な管理 を必要とする。

5. 再発例 ·二次治療例に対する動注化学療法は明ら かな予後改善効果を認めなかったので他の治療法を考慮 すべきであろう。
以上のような点がこれからこの治療を有効に活用して いくために必要だと考えられた。具体的には，若年者は 再発・多重癌発生時の治療を考えると使いにくく, 老年 者は血管病変（動脈硬化症など）の問題があり使いにく い。上顎癌は手術を併用することにより非常に成績がよ く第一選択といえる。T3 の喉頭癌, T2 の下咽頭癌で喉 頭温存を目指す, あるいは手術不能の N3 症例で動注+ 放射線治療後に原発巣の治療効果を見極めた後頸部郭清 術を行う，などの適応が考えられる。いずれにしても この治療を開始するに当たってはその適応を慎重に検討 する必要があると思われた。

\section{まとめ}

今回の検討ではより進行した症例が超選択的動注療法 を受けていたにもかかわらずその成績は手術を中心とし た治療法に匹敵するものと考えられた。この治療法は腫 瘍縮小効果に優れた局所治療であるが重篤な合併症も多 く，実際に患者を治療する際には患者の適応を十分に見 極めた上，術前の十分なコンセンサスの形成と術中・術 後の厳重な管理を必要とする。

\section{文献}

1) Robbins KT. Vicario D. et al: A targeted supradose cisplatin chemoradiation protocol for advanced head and neck cancer. Am J Surg 168: 419-422, 1994.

2) Robbins KT. Hoffman R. et al: Decadose effect of cisplatin on squamous cell casrcinoma of the upper aerodigestive tract: part I, histocultural experiment. Laryngoscope $106: 32-36,1996$.

3) Robbins KT. Storniolo AMS. et al: Decadose effect of cisplatin on squamous cell casrcinoma of the upper aerodigestive tract: part II, clinical studies. Laryngoscope 106:37-42, 1996.

4) Robbins KT. Kumar P. et al: Phase II trial of targeted supradose cisplatin (CDDP) and concommitant radiation therapy ( $R T$ ) for patients with stage $I I-I V$ head and neck cancer. Proceedings of ASCO $15: 323$, 1996.

5) Robbins KT: Targeted cisplatin chemotherapy for advanced head and neck cancer. Advances in head and neck oncology pp59-71, 1998, Singular Publishing Group, San Diego.

6) 横山純吉, 志賀清人 他 : 二経路投与法による超 選択的動注療法. 頭頸部腫㾴 $24: 18-24,1998$.

7）横山純吉, 志賀清人他：二経路投与法の超選択 的動注療法による集学的治療。頭頸部腫瘍 24 : 325-333, 1998

8）松本恒, 横山純吉他：頭頸部悪性腫瘍に対す る動注療法. Interventional Radiology手技，合併症 とその対策 25-31頁, 1998, Medical View 社, 東京. 


\title{
EVALUATION AND ANALYSIS OF SUPERSELECTIVE INTRA- ARTERIAL CHEMOTHERAPY FOR PATIENTS WITH HEAD AND NECK SQUAMOUS CELL CARCINOMA AND ITS COMPLICATIONS
}

\author{
Kiyoto SHIGA*1, Masaru TATEDA*1, \\ Junkichi YOKOYAMA*2 and Shigeru SAIJO*1 \\ ${ }^{* 1}$ Department of Head and Neck Surgery, Miyagi Cancer Center Hospital \\ ${ }^{* 2}$ Department of Otolaryngology, Tohoku University School of Medicine
}

Superselective intra-arterial (IA) chemotherapy was administered 213 times to 76 patients, from April 1995 to August 1999, in our hospital. These included 64 patients with head and neck squamous cell carcinoma, and 5 cases out of these 64 cases dropped out because of severe complications when their survival was evaluated. The five-year overall survival rate, calculated by the Kaplan-Meier method, was $49 \%$ for all patients, $78 \%$ for the patients who underwent surgery before or after IA chemotherapy ( 20 cases), and $48 \%$ for the patients who were treated by IA chemotherapy in combination with radiation therapy (26 cases). No renal failure was observed in these patients. The five-year overall survival rate was $53 \%$ for the patients with stage III or stage IV disease who were treated by surgery alone or surgery and radiation therapy ( + chemotherapy), while it was $45 \%$ for the patients with stage III or stage IV disease who were treated by IA chemotherapy and radiation therapy. Since this study was not randomized and more advanced cases tended to be treated by IA chemotherapy, this result was assumed to be good enough to improve the prognosis of the patients with advanced disease. The prognosis of the patients treated by IA chemotherapy and radiation therapy who had recurrence, or who were cases of secondary treatment, was poor and similar to that of the patients who received palliative radiation therapy ( + chemotherapy). Drop-out cases of IA chemotherapy encountered severe complications, such as 2 cerebral infarctions, one sudden death, one pneumonia with DIC, and one ARDS. There was also a sudden death, and deaths due to bleeding from local recurrent lesions after the treatment was finished. As some patients complained of dysphagia and/or dyspnea after IA chemotherapy and radiation therapy, the QOL of the patients was not very satisfactory. It is suggested that the indication of IA chemotherapy should be limited, considering the patient's condition and the location of the tumor. 